\title{
Studying the Properties of Lightweight Concrete Using Construction Materials Waste
}

\author{
Aamer Najim Abbas and Hussain Haider Abdulzahra \\ Department of Civil Engineering, Al-Muastansiriya University, Baghdad 00964, Iraq
}

\begin{abstract}
The main purpose of this research is to study the mechanical properties of lightweight concrete through the using of different types of lightweight aggregate. Three types of lightweight aggregate were used in this study for the production of lightweight concrete. These types are red block aggregate, red ceramic aggregate and white thermostone aggregate. All these types have been brought from construction waste. A comparison of the properties of lightweight concrete with normal concrete is the most important goal of this study. The most important properties of concrete, which were compared with each other is compressive strength, static modulus of elasticity, splitting tensile strength and slump flow.
\end{abstract}

Key words: Lightweight concrete, red block aggregate, red ceramic aggregate, white thermostone aggregate.

\section{Introduction}

The lower density and higher insulating capacity are the best obvious characteristics of lightweight aggregate concrete by which it distinguishes itself from ordinary normal weight concrete.

Light weight aggregate and lightweight aggregate concrete are not new materials. Lightweight aggregate concrete has been known since the early days of Roman empire. Both the colosseum and the pantheon were partly constructed with materials that can be characterized as a lightweight aggregate concrete (aggregate of crushed lava, crushed brick and pumice). In the United State, over 100 World War II ships were built in LWAC, ranging in capacity from 3,000 to 140,000 tons. Furthermore, at the time, their successful performance led to an extended use of structural LWAC in buildings and bridges [1].

Yeginbali A. et al. [2] used many types of crushed pumice rather than the normal coarse aggregate used in conventional concrete. In addition, many types of materials help to improve accepted compressive strength in structural work like silica fume and super-plastisizer. They found that the rise in

Corresponding author: Aamer Najim Abbas, master, main research field: engineering. E-mail: amir_najim@yahoo.com. compressive strength is from 29.3 $\mathrm{MPa}$ to $53.0 \mathrm{MPa}$ when using these materials.

In 2008, Zulkanain F. and Ramli M. [3] found that the using of lightweight aggregate instead of normal aggregate contributed in production good characteristics of concrete such as compressive strength, tensile strength and modulus of rupture.

Raymond T. Hemmings et al. [4] used different lightweight aggregate (pumice, expanded shale and bottom ash) and make a comparison between them and normal aggregate, they found that the compressive strength of expanded shale, pumice and bottom ash have compressive strength more than normal concrete. However, the unit weight and water demand of these materials are less than the normal aggregate unit weight and water demand.

Ozildirim Celik H. [5] studied the unit weight, splitting tensile strength and elastic modulus of LWC under different curing conditions. He used two types of aggregate: shale and clay. The results indicated that measured densities are more different than those calculated from batch weights, curing condition which affects the splitting tensile strength and elastic modulus values. Furthermore, the correlation between the results of the rapid chloride permeability test and 
surface resistivity test for a given lightweight aggregate was good.

\section{Materials}

\subsection{Cement}

The type of cement used in this study is ordinary Portland cement (type I). It is kept in a dry place to avoid atmospheric conditions. The chemical and physical analysis of the used cement are given in Tables 1 and 2 .

\subsection{Fine Aggregate}

Fine aggregate used in this study has maximum size which is less than $5 \mathrm{~mm}$. The specifications of fine aggregate are shown in Tables 3 and 4.

\subsection{Coarse Aggregate}

Coarse aggregate used in this study has maximum size which is less than $10 \mathrm{~mm}$. 100\% crushed aggregate with a minimum of flat and elongated particles is used. Table 5 shows the grading of coarse aggregate.

\subsection{Lightweight Aggregate}

Red blocks, red ceramic and white thermostone which used in this study were brought from construction waste. Table 6 shows the physical properties of these materials and Figs. 1-3 show the three types of materials.

Table 1 Chemical composition of cement.

\begin{tabular}{lll}
\hline Chemical composition & Percentage by weight & Limit of ISO: 1984 (10) \\
\hline $\mathrm{CaO}$ & 61.3 & 61.3 \\
$\mathrm{SiO}_{2}$ & 23.01 & 23.01 \\
$\mathrm{Al}_{2} \mathrm{O}_{3}$ & 5.29 & 5.29 \\
$\mathrm{Fe}_{2} \mathrm{O}_{3}$ & 3.37 & 3.37 \\
$\mathrm{MgO}$ & 2.56 & $<5$ \\
$\mathrm{SO}_{3}$ & 1.94 & $<2.8$ \\
L.O.I & 1.3 & $<4$ \\
I.R & 0.66 & $<1.5$ \\
L.S.F & 0.91 & $0.66-1.02$ \\
\hline
\end{tabular}

Table 2 Physical properties of cement.

\begin{tabular}{|c|c|c|c|}
\hline \multicolumn{2}{|c|}{ Physical properties } & Test result & Limit of I.O.S 1984 \\
\hline \multicolumn{2}{|c|}{ Fineness $\left(\mathrm{kg} / \mathrm{m}^{2}\right)$} & 3,020 & $>2,300$ \\
\hline \multicolumn{2}{|c|}{ Soundness } & $0.17 \%$ & $<0.8 \%$ \\
\hline \multicolumn{2}{|c|}{ Initial setting time } & 198 & $>45 \min$ \\
\hline \multicolumn{2}{|c|}{ Final setting time } & 4.5 & $<10 \mathrm{hr}$ \\
\hline \multicolumn{2}{|c|}{ Compressive strength ( 7 days) } & 24.9 & $>23 \mathrm{Mpa}$ \\
\hline \multicolumn{2}{|c|}{ Compressive strength (28 days) } & 41.2 & $>23 \mathrm{Mpa}$ \\
\hline No. & Sieve size $(\mathrm{mm})$ & $\begin{array}{l}\text { Present work of fine aggregate } \\
(\% \text { passing) }\end{array}$ & $\begin{array}{l}\text { BS882:1992 Limit zone "M" } \\
\text { (\% passing) }\end{array}$ \\
\hline 1 & 5 & 91.38 & $89-100$ \\
\hline 2 & 2.36 & 85.41 & $65-100$ \\
\hline 3 & 1.18 & 66.21 & $45-100$ \\
\hline 4 & 0.6 & 56.71 & $25-80$ \\
\hline 5 & 0.3 & 24.29 & $5-48$ \\
\hline 6 & 0.15 & 5.93 & $0-15$ \\
\hline
\end{tabular}


Table 4 Physical properties of fine aggregate.

\begin{tabular}{lll}
\hline No. & Properties & Results \\
\hline 1 & water absorption & $0.55 \%$ \\
2 & Specific gravity & $2.39 \%$ \\
3 & fineness modulus & $2.9 \%$ \\
4 & moisture content & $0.21 \%$ \\
\hline
\end{tabular}

Table 5 Grading of coarse aggregate.

\begin{tabular}{llll}
\hline No. & Sieve size $(\mathrm{mm})$ & $\begin{array}{l}\text { Present work of coarse aggregate } \\
\text { (\% passing) }\end{array}$ & $\begin{array}{l}\text { BS882:1992 limit } \\
\text { (\% passing) }\end{array}$ \\
\hline 1 & 20 & 100 & 100 \\
2 & 14 & 100 & $90-100$ \\
3 & 10 & 79.5 & $50-85$ \\
4 & 5 & 6.5 & $0-10$ \\
5 & 2.36 & 0 & 0 \\
\hline
\end{tabular}

Table 6 Physical properties of LWA.

\begin{tabular}{lllc}
\hline No. & Materials & Properties & Test results \\
\hline \multirow{3}{*}{1} & Red block & Dry density $\left(\mathrm{gm} / \mathrm{cm}^{3}\right)$ & 1.44 \\
& & Wet density $\left(\mathrm{gm} / \mathrm{cm}^{3}\right)$ & 1.76 \\
& Moisture content $(\%)$ & 21.9 \\
2 & Dry density $\left(\mathrm{gm} / \mathrm{cm}^{3}\right)$ & 1.61 \\
& \multirow{3}{*}{ Red ceramic } & Wet density $\left(\mathrm{gm} / \mathrm{cm}^{3}\right)$ & 1.79 \\
& & Moisture content $(\%)$ & 16.3 \\
& & Dry density $\left(\mathrm{gm} / \mathrm{cm}^{3}\right)$ & 1.52 \\
& White thermostone & Wet density $\left(\mathrm{gm} / \mathrm{cm}^{3}\right)$ & 1.69 \\
& & Moisture content $(\%)$ & 18.9 \\
\hline
\end{tabular}

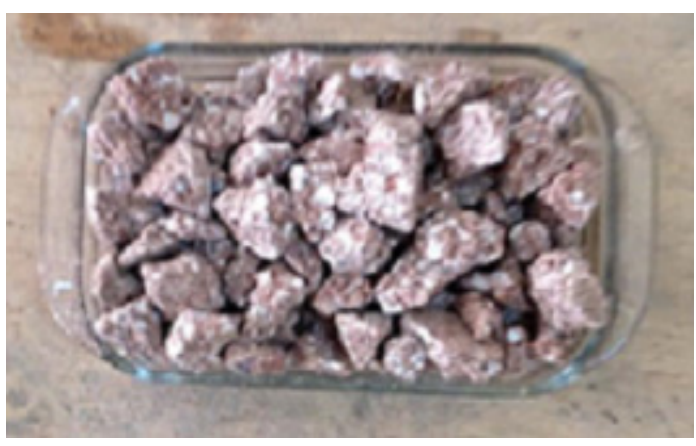

Fig. 1 Red block aggregate.

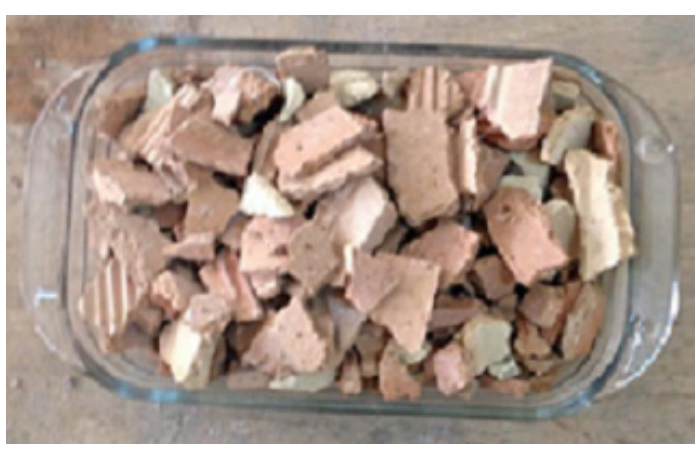

Fig. 2 Red ceramic aggregate.

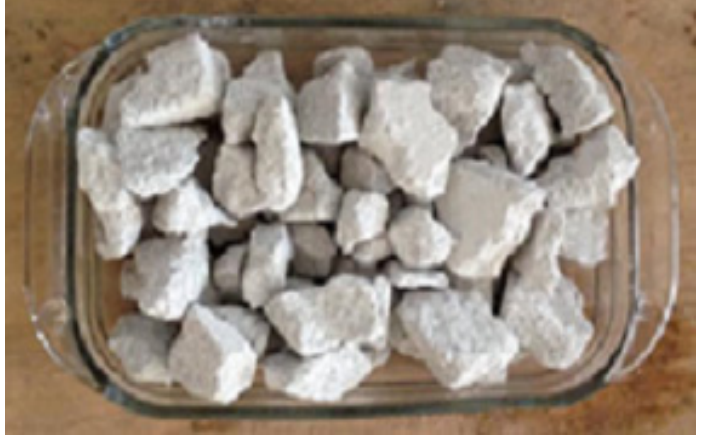

Fig. 3 White thermostone aggregate.

\section{Results and Discussion}

\subsection{Compressive Strength}

The compressive strength results of normal and lightweight concrete are summarized in Table 7 and Fig. 4. For the different mixtures, the 28-days compressive strength varied from 23.69 $\mathrm{MPa}$ to 26.83 $\mathrm{MPa}$ in case of normal weight aggregate, from 16.67 $\mathrm{MPa}$ to $19.63 \mathrm{MPa}$ in case of red block aggregate, 
Table 7 Compressive strength of tested specimens.

\begin{tabular}{llll}
\hline No. & Concrete type & Percentage of aggregate & $\begin{array}{l}\text { Compressive } \\
\text { strength (MPa) }\end{array}$ \\
\hline \multirow{3}{*}{ Normal concrete } & 0.5 & 26.83 \\
& & 0.6 & 25.1 \\
& & 0.7 & 23.69 \\
2 & Red block concrete & 0.5 & 19.63 \\
& & 0.6 & 20.39 \\
& & 0.7 & 16.67 \\
3 & Red ceramic concrete & 0.5 & 22.31 \\
& & 0.6 & 24.2 \\
& & 0.7 & 18.9 \\
& & 0.5 & 13.69 \\
& & 0.6 & 11.25 \\
& & 0.7 & 9.6 \\
\hline
\end{tabular}

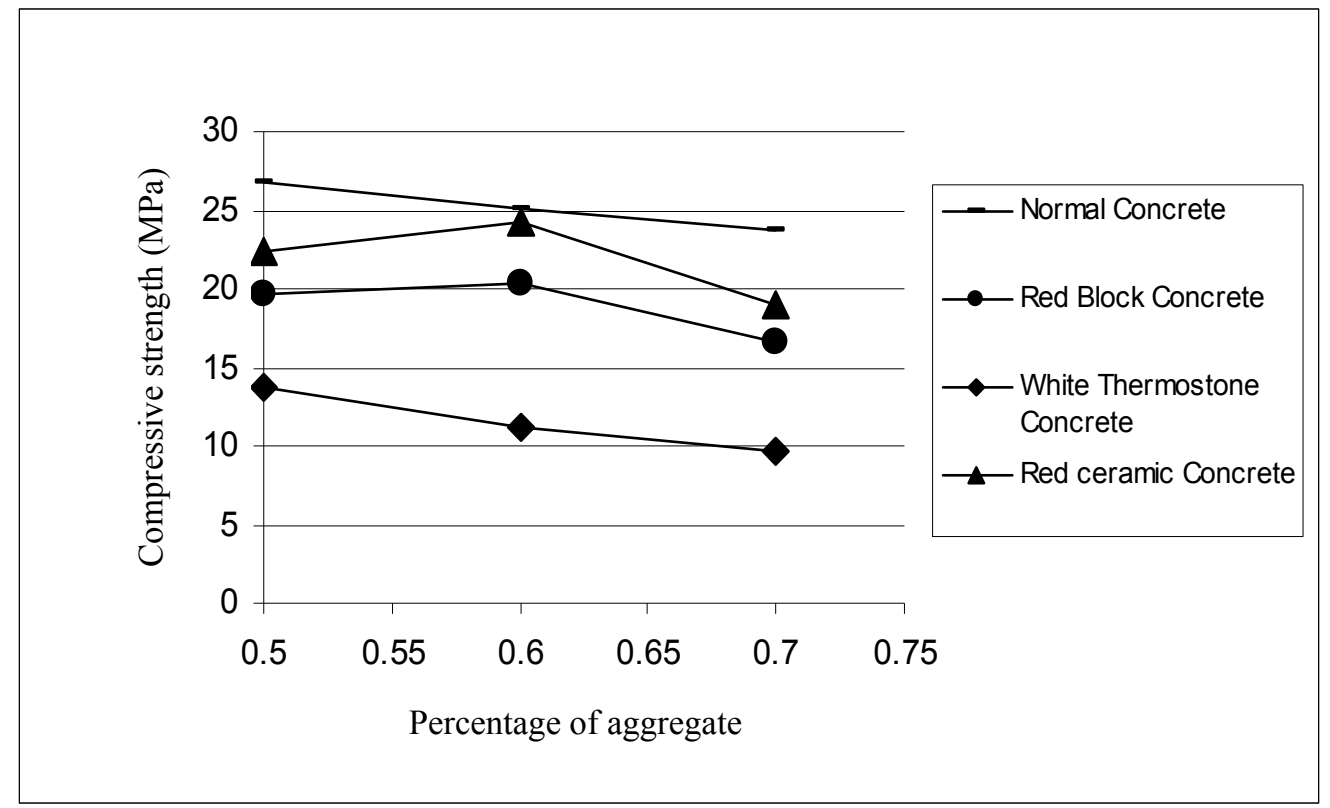

Fig. 4 Compressive strength to percentage of aggregate relationship.

from 18.9 $\mathrm{MPa}$ to $22.3 \mathrm{MPa}$ in case of red ceramic aggregate and from 9.61 $\mathrm{MPa}$ to $13.69 \mathrm{MPa}$ in case of white thermostone aggregate.

The first three types of concrete are classified as structural concrete, but the fourth type classified as non-structural concrete. It can be developed through manipulation of the mixing ratios or use some additives to improve the properties of concrete. Thus, make it structural concrete.

The decrease in the compressive strength of light weight concrete as a result of increasing the ratios of lightweight aggregate is because of the weakness of aggregate used in concrete mass $[6,7]$.

\subsection{Elastic Modulus of Elasticity}

The experimental results of elastic modulus for lightweight and normal weight concrete are shown in Table 8 and Fig. 5. It is clear that the elastic modulus of elasticity decrease with increasing lightweight aggregate ratios, this is due to the brittle nature of lightweight aggregate used in concrete mix. In other words, the elastic modulus is influenced by the elastic 
properties of aggregate [8].

\subsection{Splitting Tensile Strength}

The results of the investigation into the splitting strength of lightweight concrete with different materials and ratios are presented in Table 9 and Fig. 6. It is observed that the splitting tensile strength of normal concrete is much more than splitting tensile strength of lightweight concrete. The reduction of splitting tensile strength may be due to the lack of bond between the aggregate and cement paste.

The splitting tensile strength of red ceramic concrete is more than the other types of lightweight concretes, this rise in splitting strength is due to sharp corners that interlock with cement paste unlike the other types [9].

\subsection{Slump Test}

Through the data in Table 10 and Fig. 7, it shows that there is a clear difference among the slump values for different types.

Generally, the slump diameter for lightweight aggregate concrete is less than the normal concrete one. The roughness and porosity of aggregate reduce the movement of particles in the mixture and thereby, reduce the workability of the concrete mix. The increasing of the proportion of the pores in the surface leads to absorption of water mixture. Then, the lack of moisture content which is turn reduces the workability of concrete mix.

Table 8 Modulus of elasticity of tested specimens.

\begin{tabular}{llll}
\hline No. & Concrete type & Percentage of aggregate & Modulus of elasticity $(\mathrm{GPa})$ \\
\hline \multirow{3}{*}{1} & Normal concrete & 0.5 & 22.34 \\
& & 0.6 & 22.51 \\
& & 0.7 & 21.28 \\
2 & Red block concrete & 0.5 & 19.36 \\
& & 0.6 & 20.93 \\
& & 0.7 & 18.4 \\
3 & Red ceramic concrete & 0.5 & 19.33 \\
& & 0.6 & 20.28 \\
& & 0.7 & 19.38 \\
4 & White thermostone concrete & 0.5 & 18.21 \\
& & 0.6 & 17.93 \\
& & 0.7 & 17.22 \\
\hline
\end{tabular}

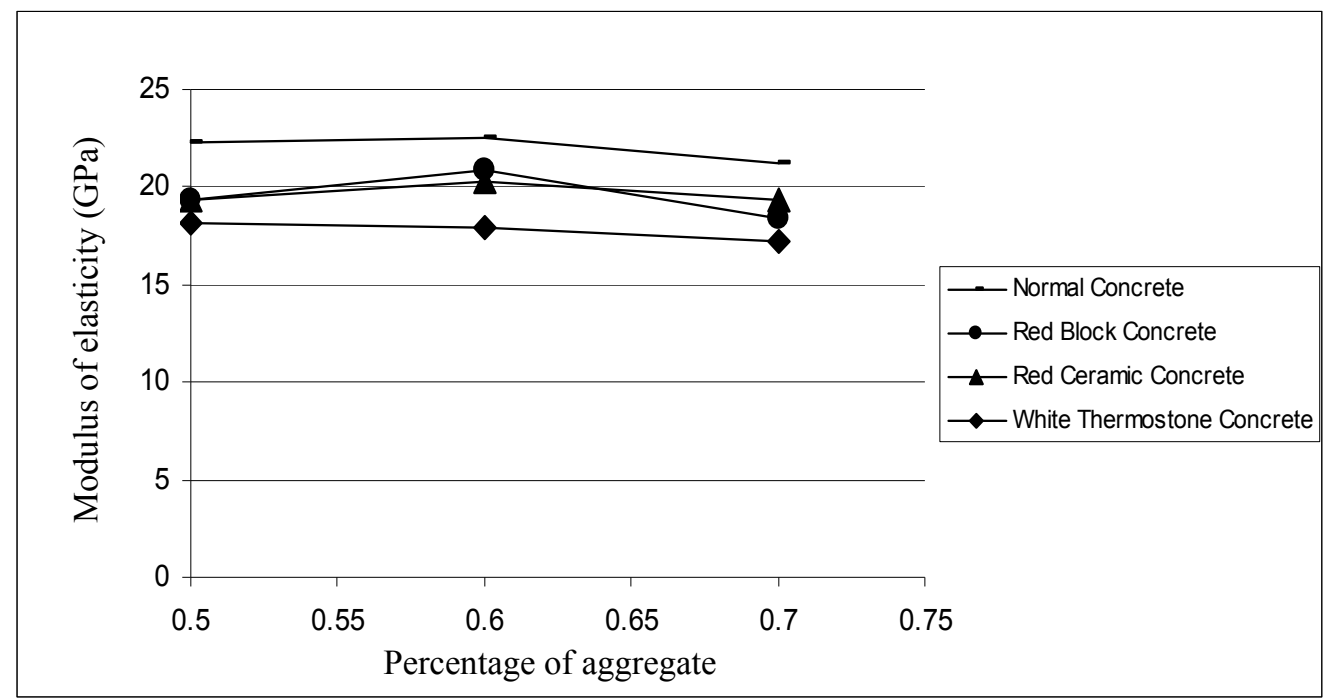

Fig. 5 Modulus of elasticity to percentage of aggregate relationship. 
Table 9 Splitting tensile strength of tested specimens.

\begin{tabular}{llll}
\hline No. & Concrete type & Percentage of aggregate & Splitting tensile strength (MPa) \\
\hline \multirow{3}{*}{ Normal concrete } & 0.5 & 4.42 \\
& & 0.6 & 4.11 \\
& & 0.7 & 3.86 \\
& Red block concrete & 0.5 & 3.43 \\
& & 0.6 & 3.48 \\
& & 0.7 & 3.26 \\
& Red ceramic concrete & 0.5 & 3.61 \\
& & 0.6 & 3.44 \\
& & 0.7 & 3.22 \\
4 & & 0.5 & 2.93 \\
& & 0.6 & 2.81 \\
\end{tabular}

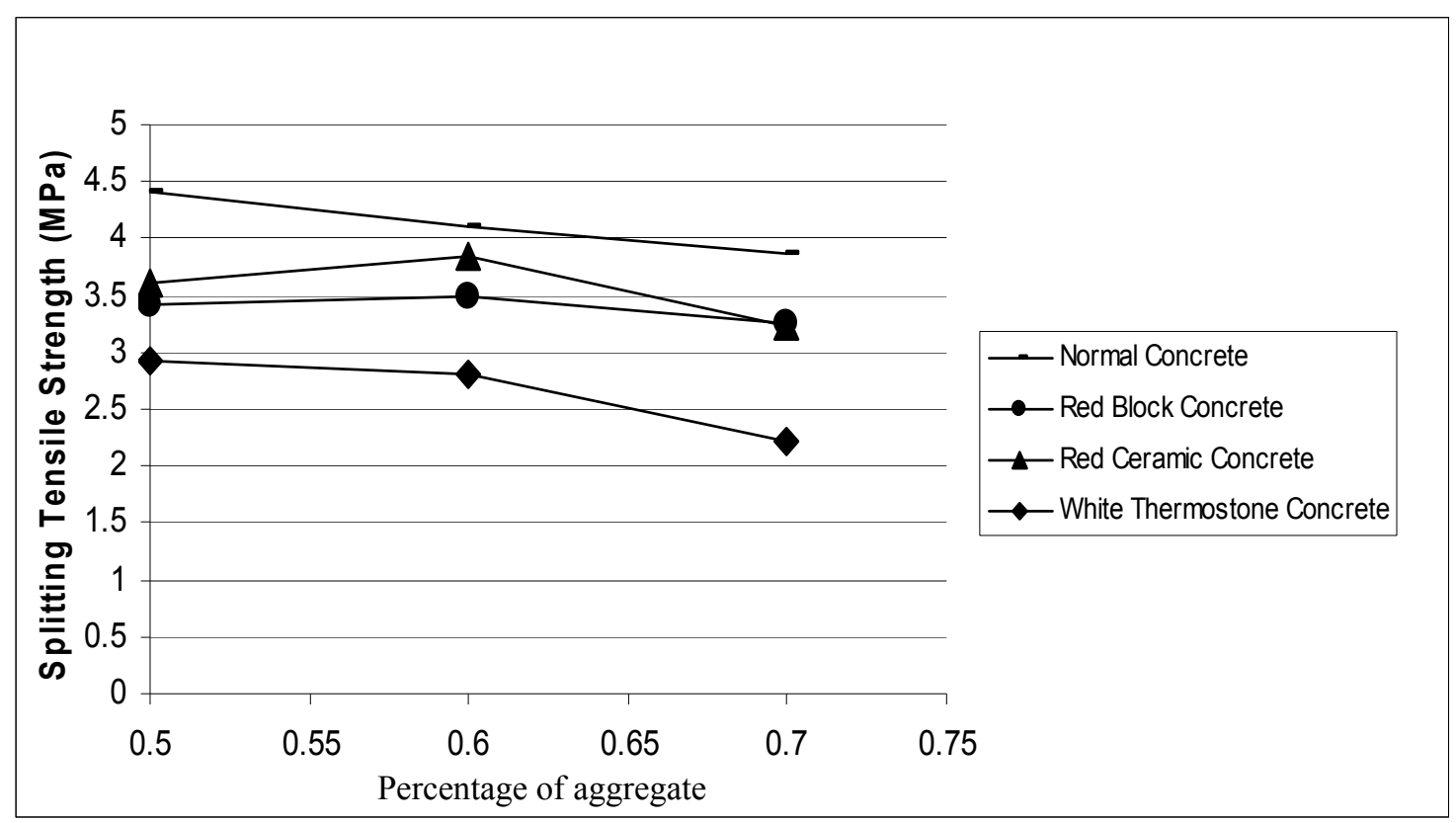

Fig. 6 Splitting tensile strength to percentage of aggregate relationship.

Table 10 Slump flow of tested specimens.

\begin{tabular}{llll}
\hline No. & Concrete type & Percentage of aggregate & $\begin{array}{l}\text { Slump flow } \\
(\mathrm{mm})\end{array}$ \\
\hline \multirow{3}{*}{ Normal concrete } & 0.5 & 420 \\
& & 0.6 & 370 \\
& & 0.7 & 310 \\
& Red block concrete & 0.5 & 320 \\
& & 0.6 & 290 \\
& & 0.7 & 250 \\
& Red ceramic concrete & 0.5 & 300 \\
& & 0.6 & 260 \\
& & 0.7 & 220 \\
& & 0.5 & 310 \\
& White thermostone concrete & 0.6 & 290 \\
& & 0.7 & 250 \\
\hline
\end{tabular}




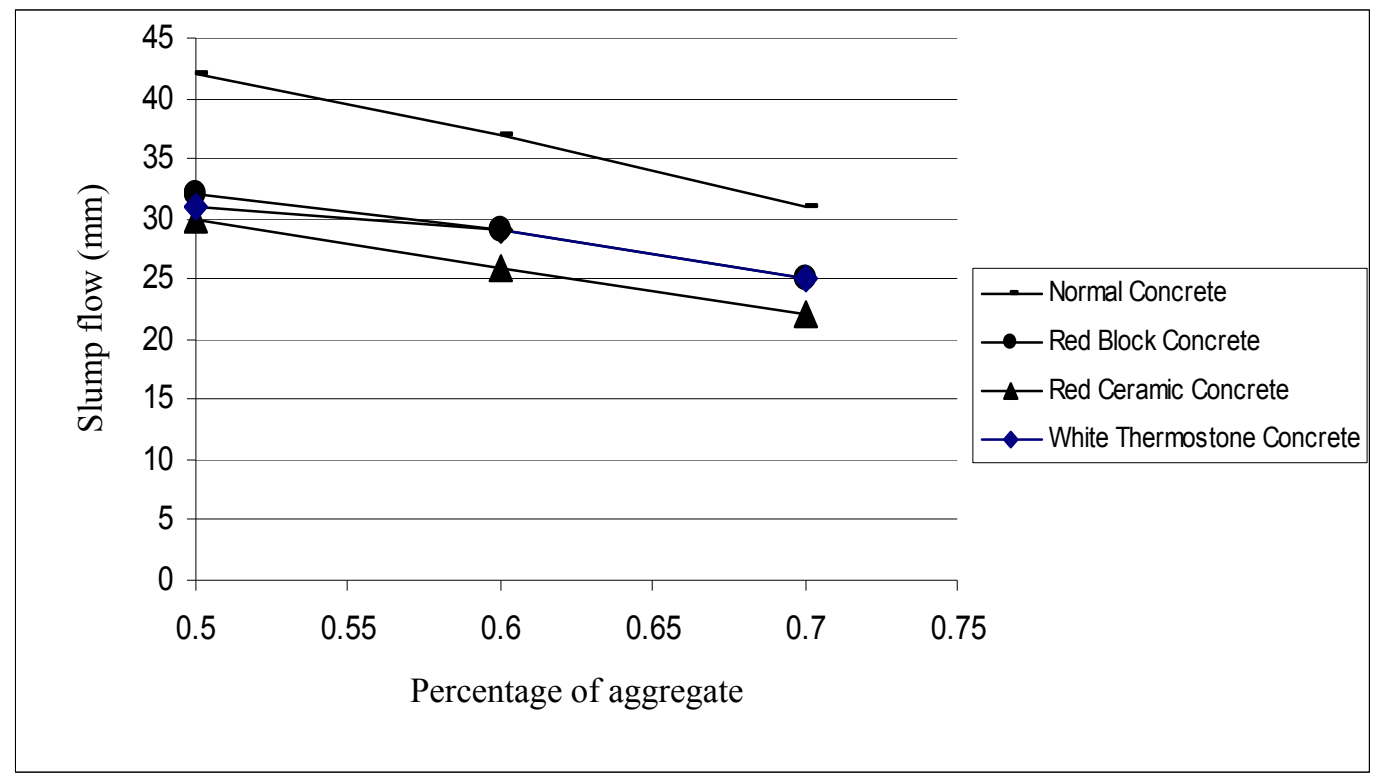

Fig. 7 Slump flow to percentage of aggregate relationship.

Also, increasing the quantity of aggregate in concrete mix can reduce some extent value of slump diameter. Because that reducing the cement paste in proportion to the amount of aggregate can make the mixture drier. As a result, if the amount of cement paste reduced to the limit that it is not sufficient to fill the space among gravel, the mixture becomes dry and inoperable $[10,11]$.

\section{Conclusions}

The mechanical properties (compressive strength, tensile strength and modulus of elasticity) of normal concrete are better than lightweight concrete.

The red ceramic concrete can be classified as the best types of lightweight concrete used in this study, in terms of compressive, tensile strength and modulus of elasticity.

The red ceramic and red block concrete can be classified as structural lightweight concrete, but the white thermostone concrete as non-structural lightweight concrete.

The slump flow of all types of concrete used in this study is within acceptable standards.

The increase in the proportion of coarse aggregate in all types of concrete used in this study reduces the compressive strength, tensile strength, modulus of elasticity and slump flow.

\section{References}

[1] Maage, M., Smeplass, S., and Thienel, K. 2000. "Structural LWAC Specifications and Guideline for Materials and Production." Second International Symposium on Structural Lightweight Aggregate Concrete. Accessed June 22, 2000. http:// www.sintef.no.

[2] Yeginobali, A. K. G., Sobolev, S. V., and Tokyay, M. 1998. "High Strength Natural Lightweight Aggregate Concrete with Silica Fume.” Accessed May 31, 2000. http://www. pantherfile.uwm.edu.

[3] Fahrizal, Zulkarnain, and Mahyuddin, Ramli. 2008. "Durability Performance of Lightweight Aggregate Concrete for Housing Construction." In 2nd International Conference on Built Environmental in Developing, 541-551.

[4] Raymond, T., Hemmings, Bruce, J., Cornelius, Paul, Yuran, and Milton, Wu. 2009. "Comparative Study of Lightweight Aggregate." In World Coal Ash (WOCA) Lexington Conference, 1-15.

[5] Celik, Ozyildirim, H. 2011. Laboratory Investigation of Lightweight Concrete Properties. Vinginia Center for Transportion Report.

[6] BS (1881): Part (115). 1986. Specifications for Compression Testing Machines for Concrete. London: International British Standard.

[7] ASTM C39. 1986. Test Method for Compressive Strength of Cylindrical Concrete Specimens. Philadelphia: 
American Society for Testing and Materials.

[8] BS (1881): Part (117). 1983. Method of Determination of Tensile Splitting Strength. London: International British Standard.

[9] ASTM C469. 1986. Standard Test Method for Static Modulus of Elasticity and Pisson's Ratio of Concrete in Compression. Philadelphia: American Society for Testing and Materials.

[10] IOS. 1984. Iraqi Standard (5), Portland Cement. Baghdad: General Organization for Standardization and Quality Control.

[11] BS (882). 1992. Specifications for Aggregates from Natural Sources for Concrete. London: International British Standards. 